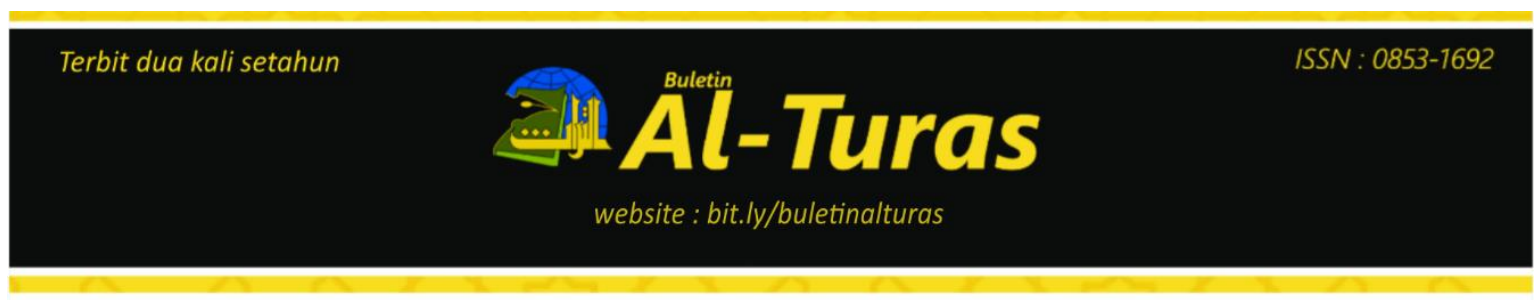

\title{
Representasi LGBT dalam Perspektif Ideologi Khilafah: Kajian Transitivitas dalam Buletin Kaffah
}

\author{
Dede Fatinova \\ Universitas Pamulang \\ Banten, Indonesia \\ dedefatinova@gmail.com
}

\author{
Ratna Juwitasari Emha \\ Universitas Pamulang \\ Banten, Indonesia \\ ratna.juwitaemha@yahoo.com
}

\author{
Yasir Mubarok \\ Universitas Pamulang \\ Banten, Indonesia \\ yasirmubarok1@gmail.com
}

\begin{abstract}
Abstrak
Ideologi khilafah merupakan sebuah ideologi yang kerap kali diinterpretasikan sebagai ideologi yang cukup radikal. Umumnya ideologi khilafah menyoroti isu-isu politik yang bertentangan dengan syariat Islam. Namun, kali ini ideologi khilafah juga menyoroti isu sosial, yaitu LGBT. LGBT merupakan isu yang kontroversial secara global. Sementara ideologi khilafah merupakan sebuah paham yang konsepnya bertentangan dengan negara Indonesia. Penyebaran ideologi khilafah sudah dilarang oleh pemerintah Indonesia. Namun eksistensinya masih hadir dalam rupa yang baru, yaitu pada sebuah buletin bernama KAFFAH. Kajian ini akan mengungkapkan bagaimana LGBT direpresentasikan dalam perspektif ideologi khilafah. Data dalam penelitian ini berasal dari artikel tentang LGBT pada media Kaffah, edisi 025 yang dirilis pada 26 Januari 2018. Selanjutnya data dikaji secara kualitatif dengan metode analisis deskriptif. Penelitian ini menggunakan pendekatan teori Transitivitas sebagai teori yang menyatakan bahwa bahasa merupakan representasi dari pengalaman manusia. Transitivitas ini berfokus pada tiga komponen, yaitu proses, partisipan, dan sirkumtan. Berdasarkan uraian Transitivitas, diketahui bahwa dalam perspektif ideologi khilafah, LGBT bukan hanya direpresentasikan sebagai masalah sosial, tapi juga sebagai implikasi dari tidak adanya Undangundang yang bersumber dari hukum Islam yang secara eksplisit dapat menjerat LGBT.
\end{abstract}

Kata kunci: ideologi; LGBT; representasi; transivitas

\section{Abstract}

The khilafah ideology is an ideology that is often interpreted as a fairly radical ideology. Generally, the ideology of the khilafah highlights political issues that are contrary to Islamic law. However, the Khilafah ideology also highlights social issues, namely LGBT. LGBT is a controversial issue globally. While the khilafah ideology is a concept that is contrary to the Indonesian state. The Indonesian government has banned the spread of the khilafah ideology. But its existence is still present in a new form such as a bulletin called KAFFAH. This study aims to describe how LGBT is represented in the perspective of khilafah. The data of this study is a KAFFAH bulletin article, 025 editions, which released on January 26, 2018. Furthermore, the data were analyzed qualitatively by descriptive analysis methods. This study uses the Transitivity theory approach as a theory which states that language is a representation of human experience. The Transitivity focuses on three components; process, participants, and circumstance. Based on the description of Transitivity, LGBT is not only represented as a social problem but also as an implication of the absence of laws that originate from Islamic law which can explicitly ensnare LGBT.

Keywords: ideology; LGBT; representation; transitivity 


\section{A. Pendahuluan}

LGBT dan khilafah merupakan dua isu yang mengundang pro dan kontra di kalangan masyarakat Indonesia. LGBT dinilai bertentangan dengan konstitusi yang berlaku di negara Indonesia. Khilafah pun dinilai sebagai paham yang konsepnya bertentangan dengan falsafah negara Indonesia.

Pada hakikatnya, LGBT merupakan isu yang kontroversial secara global. Eksisten-sinya di Indonesia mengundang pro dan kontra dari banyak pihak. Pihak pro menilai LGBT sebagai hak-hak dasar warga negara. Banyaknya kaum LGBT yang mengalami tindak kekerasan semakin diperparah dengan adanya undang-undang yang cenderung diskriminatif terhadap LGBT, misalnya Undang-Undang terhadap Pornografi dan Pornoaksi (2006).

Implikasi dari adanya undang-undang tersebut adalah munculnya sifat intoleran dari masyarakat terhadap kaum LGBT di Indonesia. Hal ini tercermin dari beberapa kasus di Indonesia yang melibatkan LGBT sebagai korban. Misalnya, kasus hukum cambuk pasangan gay di Aceh, penggerebekan pesta gay di Jakarta, dan pernikahan gay di Bali. Kasus-kasus tersebut merupakan contoh dari tindakan intoleransi besar-besaran yang dilakukan masyarakat terhadap kaum LGBT sebagai kaum minoritas di negara yang berbasis demokrasi ini.

Di sisi lain, pihak kontra menyatakan bahwa eksistensi LGBT pada hakikatnya lebih berbahaya dibandingkan dengan kejahatan terorisme dan narkoba."1 Selain itu, LGBT pun tidak selaras dengan sistem

\footnotetext{
${ }^{1}$ Maskur, "LGBT Lebih Berbahaya Ketimbang Terorisme \& Narkoba."

2 Pratiwi, "Konstruksi Realitas Dan Media Massa (Analisis Framing Pemberitaan Lgbt Di Republika Dan Bbc News Model Robert N. Entman)"; Putra and Nasionalita, "Isu Lgbt Dalam Bingkai Media Online"; Suranto, Herlina, and Setiawan, "Agama Dan Media Diskursus LGBT Dalam Opini SKH Republika"; Lingga and Syam, "Analisis Framing Pemberitaan Lesbian, Gay, Biseksual Dan
}

agama dan budaya yang berlaku di Indonesia. Hal ini dikarenakan LGBT berbenturan dengan norma sosial dan adat istiadat yang ada. Di samping itu, LGBT pun memiliki risiko besar dalam penularan penyakit HIV/AIDS.

Lebih lanjut, pihak kontra menginginkan adanya hukum yang jelas tentang pelarangan eksistensi LGBT di Indonesia, karena pada hakikatnya LGBT bertentangan dengan konstitusi yang berlaku di Indonesia.

Perdebatan mengenai LGBT pun mencapai ranah ruang publik. Berbagai media menunjukkan posisi keberpihakannya terkait eksistensi LGBT di Indonesia. Hal ini terbukti dengan ditemukannya berbagai peneliti yang mengungkap bagaimana sikap media dalam menyikapi isu tersebut. ${ }^{2}$

Dari hasil kajian tersebut ditemukan bahwa media yang seharusnya menjaga profesionalitas untuk mengedepankan nilai-nilai universal, cerdas dan profesional malah melakukan hal sebaliknya. Hal ini dikarenakan media menempati posisi strategis yang memiliki kemampuan sebagai sarana legitimasi."3 Media massa pun bukan suatu yang bebas dan independen, akan tetapi memiliki keterkaitan dengan realitas sosial, seperti kepentingan media, kepentingan pemilik modal, dan kepentingan ideologi antar masyarakat dan negara. Kenyataan inilah yang menyebabkan adanya beberapa media yang melakukan foregrounding dan backgrounding dalam memberitakan sebuah berita. $^{4}$ Hal ini dikarenakan

Transgender (LGBT) Pada Media Online Republika.Co.Id Dan Tempo.Co"; Nirwanto, "Pembingkaian Berita Pro Kontra LGBT Di Laman Topik Pilihan Kompas.Com (How Kompas.Com Frame News on the Pros and Cons of LGBT in Their Selected Topics Page)."

${ }^{3}$ Sobur, Analisis Teks Media: Suatu Pengantar Untuk Analisis Wacana.

${ }^{4}$ Sobur. 
wacana media kental akan syarat kepentingan dan ideologi. ${ }^{5}$

Perdebatan mengenai eksistensi LGBT disebabkan oleh tidak adanya dasar hukum yang jelas. Fakta ini mengindikasikan adanya kekosongan hukum dan menimbulkan ruang bagi gagasan atau perilaku apa pun, baik yang tidak masuk akal agar dapat dibuat landasan hukumnya. Hal ini pun yang sebenarnya diperjuangkan oleh LGBT, yaitu adanya pengakuan dari pemerintah untuk mengategorikan LGBT sebagai wujud dari keragaman gender. Terkait dengan hal tersebut, untuk saat ini gender yang diakui di Indonesia hanyalah lakilaki dan perempuan. ${ }^{6}$

Samarnya payung hukum terhadap LGBT yang berkelanjutan akhirnya mendapat perhatian pemerintah. Oleh karena itu, pada tahun 2018 DPR dan pemerintah sempat membahas RUU KUHP untuk mengatur status hukum LGBT di Indonesia.

Polemik ketidakjelasan dasar hukum LGBT tersebut menjadi keresahan sejumlah kalangan praktisi dan akademisi perempuan yang dipelopori oleh guru besar bidang Ketahanan Keluarga IPB, Prof. Dr. Euis Sunarti. Kelompok tersebut kemudian secara legal melayangkan surat permohonan kepada MK pada tanggal 19 April 2016 agar melakukan pengujian konstitusionalitas terhadap sejumlah pasal dan secara tersurat juga mengusulkan agar LGBT dapat dikategorikan sebagai delik tindak pidana murni, sama seperti perbuatan zina (Pasal 284), pemerkosaan (Pasal 285), dan pencabulan (Pasal 292).

Sayangnya, empat dari sembilan hakim di Mahkamah Konstitusi yang melakukan pengujian menyatakan pendapat berbeda (dissenting opinion).

\footnotetext{
${ }^{5}$ Munfarida, “analisis wacana kritis dalam perspektif norman fairclough."

${ }^{6}$ Putra and Nasionalita, "Isu Lgbt Dalam Bingkai Media Online."

${ }^{7}$ Husaini, LGBT Di Indonesia: Perkembangan Dan Solusinya; Tim Legality, KUHP (Kitab Dan
}

Pada akhirnya MK menolak permohonan pengujian konstitusionalitas pada pasalpasal tersebut, hal ini tertera pada PUTUSAN Nomor 46/PUU-IV/2016.

Fakta dalam putusan menunjukkan bahwa memperluas jenis delik pidana bukanlah wewenang MK, melainkan wewenang DPR dan Presiden. Hal tersebut diperjelas oleh Prof. Mahfud MD yang menyatakan bahwa MK tidak memiliki wewenang untuk menguji sebuah Rancangan Undang-undang (RUU).

Sebagai respon putusan MK tersebut dibuatlah RUU KUHP Pasal 492 yang menyatakan bahwa:

"setiap orang yang melakukan perbuatan cabul dengan orang lain yang sesama jenis kelaminnya yang diketahui atau patut diduga belum berumur 18 (delapan belas) tahun, dipidana paling singkat 1 (satu) tahun dan paling lama 7 (tujuh) tahun”.

Namun, draf tersebut hanyalah bentuk repetisi dari Pasal 292 KUHP tentang Kejahatan terhadap kesusilaan yang berisi:

"orang dewasa yang melakukan perbuatan cabul dengan orang lain sesama kelamin, yang diketahuinya atau sepatutnya harus diduganya belum dewasa, diancam penjara paling lama lima tahun." 7

Sampai saat ini RUU tersebut belum juga disahkan sehingga regulasi KUHP dipandang belum mencakup dan menyelesaikan permasalahan LGBT di Indonesia. ${ }^{8}$ Pada akhirnya, LGBT tetap

Undang-Undang Hukum Pidana) Dan KUHAP (Kitab Undang-Undang Hukum Acara Pidana).

8 Artina, "Kedudukan LGBT Dalam Hukum Negara Republik Indonesia Ditinjau Dari Perspektif Pancasila." 
tidak memiliki fondasi hukum yang jelas di Indonesia.

Indonesia sebagai negara demokrasi yang menjunjung tinggi nilai-nilai Pancasila dan budaya ketimuran, pada permasalahan LGBT ini, dihadapkan dengan suatu keputusan yang dapat dikatakan sulit untuk ditentukan arah hukumnya. Pada hakikatnya, fenomena LGBT di Indonesia dapat ditinjau dari dua perspektif berbeda, yaitu Pancasila dan UUD 1945. Meskipun berpijak pada landasan yang sama, namun menghasilkan sudut pandang yang berbeda.

Dari perspektif Pancasila, khususnya sila ke-1 yang berbunyi "Ketuhanan Yang Maha Esa" menunjukkan bahwa nilai atau pilar keseimbangan jiwa bangsa Indonesia yang dianggap memiliki derajat tertinggi dan tidak dapat dibantah adalah nilai Ketuhanan. Sehingga segala perbuatan yang dilakukan oleh masyarakat Indonesia harus sesuai dengan tuntunan Tuhan yang telah tertulis dalam kitab suci.

Hal ini mengindikasikan bahwa LGBT merupakan suatu bentuk perbuatan yang bertentangan dengan ketentuan Tuhan dan seharusnya keberadaannya dilarang di Indonesia $^{9}$ Hal ini sangat kontras jika ditinjau dari perspektif UUD 1945 khususnya pada Pasal-pasal tentang HAM. Pasal 28D Ayat 1 yang berbunyi:

"Setiap orang berhak atas pengakuan, jaminan, perlindungan, dan kepastian hukum yang adil serta perlakuan yang sama di hadapan hukum"10

\footnotetext{
${ }^{9}$ Harahap, Kamalludin, and Arzaqi, "Kebijakan Hukum Pidana Dalam Upaya Menanggulangi LGBT (Lesbian, Gay, Biseksual, Dan Transgender) Berbasis Pancasila."

10 Katjasungkana and Wieringa, Kriminalisasi Merayap: Pemetaan Undang-Undang Nasional Serta Peraturan Daerah Di Indonesia Yang Melanggar Hak Asasi Perempuan Dan Kelompok LGBTQ.

${ }^{11}$ Syamsul, "Buletin Kaffah Diduga Milik HTI Masih Menyebar Di Jombang”; Hanifudin,
}

Pasal tersebut secara eksplisit menunjukkan bahwa Konstitusi Indonesia akan menjamin hak untuk hidup, bekerja, dan berkeluarga bagi masyarakat Indonesia. Tidak hanya itu, ayat tersebut pun mengindikasikan bahwa Konstitusi Indonesia seyogyanya harus dapat memberikan jaminan kebebasan untuk berekspresi dan berkumpul, termasuk hak untuk mengembangkan diri serta jaminan hukum bagi seluruh warga negara, tidak terkecuali kaum LGBT. Perbedaan perspektif tersebut mengindikasikan bahwa terdapat dua ideologi masyarakat dalam menilai LGBT, yaitu liberalis dan konservatif.

Selain dua ideologi tersebut, terdapat ideologi lain yang juga turut beropini terkait eksistensi LGBT di Indonesia, yaitu ideologi khilafah. Umumnya, ideologi khilafah ini terfokus pada isu-isu politik di Indonesia. Namun, kini khilafah pun menanggapi isu sosial, yaitu LGBT. Fenomena LGBT ini dimuat dalam artikel buletin KAFFAH. Buletin ini diduga kuat milik ormas Hizbut Tahrir Indonesia (HTI) sebagai ormas yang mengusung paham khilafah. ${ }^{11}$

HTI adalah organisasi masyarakat yang dikenal memiliki ideologi khilafah. ${ }^{12} \mathrm{HTI}$ menyebarkan agendanya dengan menekankan pada kewajiban bagi Muslim untuk menciptakan kembali kekhalifahan Islam. $^{13}$ Ormas ini secara resmi dibubarkan dan kemudian dilarang oleh pemerintah pada Juli 2017 melalui Perpu Nomor 2 Tahun 2017. ${ }^{14}$ Pencabutan badan hukum disebabkan ormas HTI dianggap ingin mengubah haluan negara.

\footnotetext{
"Kaffah HTI Masih Tersebar Luas, Bagaimana Cara Menyikapinya?"; mm, "Buletin Jumat Kaffah HTI Sebarkan Anti Islam Nusantara."

${ }^{12}$ Rauf, "The Implication of Caliphate Ideology Movements against the Implementation of Democracy toward Jember Society."

${ }^{13}$ Kartini, "Hizbut Tahrir Indonesia and the Idea of Restoring Islamic Caliphate."

${ }^{14}$ Movanita, "HTI Resmi Dibubarkan Pemerintah?"
} 
Berkaitan dengan ini, Menkopolhukam, Wiranto sempat mengingatkan agar para eks-HTI tidak menyebarkan paham khilafahnya. ${ }^{15}$

Secara etimologi, kata khilafah berasal dari خَخَفَ ـ خِلاَفَة/khalafa - khilafatan/ yang artinya menggantikan. Di Indonesia, khilafah erat kaitannya dengan sebuah paham yang ingin menjadikan aturan Islam sebagai dasar hukum negara. Menurut ideologi khilafah, segala permasalahan yang dihadapi negara dapat diselesaikan jika saja negara mengadopsi aturan Islam sebagai asas negara. ${ }^{16}$

Sementara itu, ideologi merupakan sebuah sistem semantik yang menyampaikan makna. ${ }^{17}$ Sebuah ideologi merepresentasikan keinginan, harapan, dan nilai berdasarkan sistem yang telah ditentukan.

Ideologi khilafah merupakan sebuah ideologi yang mengusung konsep kekhilafahan. Dalam praktiknya, ideologi khilafah ini menilai bahwa sistem pemerintahan di Indonesia merupakan sistem dan ideologi yang keliru. Ideologi ini pada dasarnya menginginkan adanya perubahan sistem politik di Indonesia. ${ }^{18}$ Dari yang semula merupakan sistem politik yang berkiblat ke Barat, menjadi sistem politik khilafah Islamiyah sesuai dengan syariat Islam.

Sementara itu, jika melihat dari perspektif teori Barthes, konsep kekhilafahan di Indonesia merupakan sebuah mitos dan tidak dapat dijadikan sebuah konsep atau ide. ${ }^{19}$ Dengan kata

\footnotetext{
${ }^{15}$ Prasetya, "Wiranto Tegaskan Eks HTI Dilarang Sebar Paham Khilafah."

${ }^{16}$ Sabara, "Hizbut-Tahrir in Da'wah and Islamic Political Movements in Indonesia."

${ }^{17}$ Heck, Culture, Media, and Language.

${ }^{18}$ Shobron, "Model Dakwah Hizbut Tahrir Indonesia."

${ }^{19}$ Jaelani and Sulistyaningtyas, "Kontroversi Khilafah: Islam, Negara, Dan Pancasila."

${ }^{20}$ Artina, "Kedudukan LGBT Dalam Hukum Negara Republik Indonesia Ditinjau Dari Perspektif Pancasila"; Harahap, "LGBT Di Indonesia: Perspektif Hukum Islam, HAM, Psikologi, Dan Pendekatan Maslahah.”; Harahap,
}

lain, wacana konsep kekhilafahan di Indonesia tidak tepat karena Indonesia terdiri atas masyarakat yang majemuk dan memiliki Hak Asasi Manusia (HAM).

Hal ini sebagaimana yang diungkapkan oleh Maruf Amin, Ketua MUI yang menyatakan bahwa konsep khilafah di Indonesia itu tertolak karena Indonesia sudah memiliki Pancasila sebagai dasar hukum negara.

Bertolak pada fenomena LGBT dan ideologi khilafah tersebut, maka representasi LGBT dalam perspektif ideologi khilafah menjadi menarik untuk dikaji lebih dalam. Kajian ini akan dianalisis melalui analisis teks makna ideasional-eksperensial untuk mengeksplorasi bagaimana LGBT direpresentasikan dalam perspektif ideologi khilafah.

Ikhwal penelitian representasi LGBT, terdapat beberapa penelitian terdahulu yang dinilai relevan dengan penelitian ini.

Namun, dari penelusuran yang penulis lakukan, kajian mengenai representasi LGBT dalam teks media masih belum banyak dilakukan. Umumnya, kajian tersebut lebih banyak ditinjau dari perspektif ilmu hukum. ${ }^{20}$

Adapun beberapa penelitian yang mengkaji representasi LGBT dalam media massa sudah dilakukan sebelumnya. Kajian yang dilakukan oleh Suranto menganalisa representasi LGBT dalam opini SKH Republika. Berdasarkan penelitian tersebut, dapat disimpulkan bahwa Republika cenderung mengarah

Kamalludin, and Arzaqi, "Kebijakan Hukum Pidana Dalam Upaya Menanggulangi LGBT (Lesbian, Gay, Biseksual, Dan Transgender) Berbasis Pancasila."; Irawan, "Irawan, Edi. 2017. Hukuman Bagi Pelaku Homoseksual Dan Lesbian Dalam Perspektif Hukum Islam Dan Hukum Positif"; Yansyah and Rahayu, "Globalisasi Lesbian, Gay, Biseksual, Dan Transgender (LGBT): Perspektif HAM Dan Agama Dalam Lingkup Hukum Di Indonesia"; Yudah and Sulhin, "Representasi Transgender Dan Transeksual Dalam Pemberitaan Di Media Massa: Sebuah Tinjauan Analisis Wacana Kritis.” 
pada ideologi konservatif. Hal ini terlihat dari strategi Republika yang dengan sengaja memilih aktor-aktor tertentu yang berafiliasi sesuai dengan ideologinya. Hal ini bertujuan agar wacana yang berkembang sesuai dengan perspektif media. Dampaknya adalah tersudutnya posisi LGBT dalam pemberitaan media tersebut. $^{21}$

Penelitian selanjutnya membandingkan bagaimana media Kompas dan Republika merepresentasikan LGBT. Hasilnya menunjukkan bahwa representasi LGBT dalam media Kompas cenderung posistif, sementara dalam media Republika cenderung negatif. ${ }^{22}$

Sementara itu, dalam penelitian ini penulis mencoba untuk mengungkapkan bagaimana representasi LGBT dalam media Kaffah sebagai media yang mengusung ideologi khilafah.

\section{B. Metode}

Secara umum penelitian ini berfokus pada bagaimana LGBT direpresentasikan dalam perspektif ideologi Khilafah. Penelitian ini merupakan penelitian kualitatif dengan menggunakan metode analisis deskriptif. Data dalam penelitian ini berasal dari artikel pada buletin KAFFAH edisi 025 yang dirilis pada 26 Januari 2018 M. Selanjutnya data dianalisis dengan menggunakan teori Transitivitas yang berfokus pada makna ideasional, meliputi proses, partisipan, dan sirkumtan. ${ }^{23}$

\section{Temuan dan Pembahasan Uraian Sistem Transitivitas}

Transitivitas merupakan alat untuk menganalisa representasi. Artinya, pondasi utama untuk menganalisis

\footnotetext{
${ }^{21}$ Suranto and Setiawan, "Agama Dan Media: Diskursus LGBT Dalam Opini SKH Republika."

${ }^{22}$ Fatinova, "Representasi LGBT (Lesbian, Gay, Biseksual, Dan Transgender) Dalam Pemberitaan Di Kompas.Com Dan Republika.Co.Id (Kajian Linguistik Sistemik Fungsional)."

${ }^{23}$ Halliday and Mathiessen, Halliday's Introduction to Functional Grammar.
}

representasi adalah melalui kajian transitivitas. $^{24}$ Tiga unsur yang dikaji dalam transitivitas, yaitu proses, partisipan, dan sirkumtan. Makna dalam ketiga komponen tersebut menjelaskan sebuah pengalaman yang direalisasikan dalam struktur kebahasaan. ${ }^{25}$

\section{Proses}

Elemen pertama dalam kajian transitivitas adalah proses. $^{26}$ Proses merupakan unsur wajib dalam transitivitas. Dalam sebuah klausa, proses direalisasikan oleh verba. Proses terbagi menjadi enam jenis, yaitu material, mental, behavioural, verbal, dan eksistensial. ${ }^{27}$ Fungsi dari analisis proses adalah untuk menjelaskan berbagai peristiwa yang terjadi (happening), yang dilakukan (doing), dirasakan (sensing), diucapkan (saying), atau yang dimiliki (having). Jenis dan frekuensi kemunculan proses dalam teks media KAFFAH dapat dilihat pada Tabel 1.

Tabel 1. Jenis Proses dan Kemunculannya dalam artikel buletin KAFFAH

\begin{tabular}{|c|c|c|c|c|}
\hline No. & Process Type & & $\mathrm{F}$ & $\%$ \\
\hline 1. & Material & & 50 & 47,6 \\
\hline 2. & Mental & & 10 & 9,52 \\
\hline \multirow{2}{*}{3.} & \multirow{2}{*}{ Relational } & Attributive & 8 & 7,62 \\
\hline & & Identifying & 8 & 7,62 \\
\hline 4. & Behavioural & & 5 & 4,76 \\
\hline 5. & Verbal & & 19 & 18,1 \\
\hline \multirow[t]{2}{*}{6.} & Existential & & 5 & 4,76 \\
\hline & & Total & 105 & 100 \\
\hline
\end{tabular}

Dari Tabel 1 di atas, dapat dilihat bahwa artikel LGBT dalam teks buletin media KAFFAH lebih didominasi oleh proses material dengan persentase sebesar 47,6\%. Hal ini mengindikasikan bahwa KAFFAH cenderung menonjolkan kegiatan yang melibatkan fisik atau

\footnotetext{
${ }^{24}$ Hart, Discourse, Grammar, and Ideology.

${ }^{25}$ Wiratno, Pangantar Ringkas Linguistik Sistemik Fungsional.

${ }^{26}$ Hart, Discourse, Grammar, and Ideology.

${ }^{27}$ Halliday and Mathiessen, Halliday's

Introduction to Functional Grammar.
} 
kejadian suatu peristiwa yang melibatkan adanya partisipan aktif dan sasaran.

Penggunaan proses material yang digunakan media KAFFAH dapat dibagi menjadi tiga kategori, yaitu proses material berkonotasi positif, negatif, dan netral. Proses material berkonotasi positif terlihat dari penggunaan kata-kata seperti memberikan, mendukung, dan melindungi. Proses material berkonotasi negatif terlihat dari penggunaan kata-kata seperti menolak dan melakukan kekerasan. Sementara proses material berkonotasi netral terlihat dari penggunaan kata-kata seperti menghadiri dan menempati.

Perlu menjadi perhatian adalah umumnya penggunaan kata-kata berkonotasi positif akan mencitrakan partisipan secara positif, namun dalam konteks kalimat yang ada pada media Kaffah, proses berkonotasi positif justru memberikan citra yang negatif terhadap partisipannya. Hal ini dapat dilihat dari klausa kompleks "Aparat kepolisian harus melindungi LGBT'. Pada dasarnya, kata "melindungi" adalah proses berkonotasi positif, namun setelah partisipan sasaran yang mengiringinya adalah "LGBT" maka partisipan aktif (polisi) dalam proses tersebut memiliki citra negatif karena dinilai sebagai pihak yang mendukung gerakan yang salah. LGBT dalam perspektif ideologi khilafah, bukanlah sesuatu yang harus dilindungi.

\section{Partisipan}

Elemen kedua dalam kajian transitivitas adalah Partisipan. Partisipan merupakan entitas yang melekat pada proses sebagai unsur wajib dari transitivitas. Dalam sebuah klausa, partisipan direalisasikan oleh nomina. Setiap proses memiliki partisipannya masing-masing. Wujudnya dapat berupa manusia maupun non-manusia. Analisis partisipan ini dapat menunjukkan bagaimana sebuah entitas tertentu ditempatkan dalam sebuah teks pemberitaan. Jenis dan frekuensi kemunculan partisipan dalam teks media KAFFAH dapat dilihat pada Tabel 2.

Tabel 2. Jenis Partisipan dan Kemunculannya dalam artikel buletin KAFFAH

\begin{tabular}{|c|c|c|c|c|}
\hline $\begin{array}{c}\text { No } \\
\text {. }\end{array}$ & $\begin{array}{l}\text { Process } \\
\text { Type }\end{array}$ & Participants & $\mathrm{F}$ & $\%$ \\
\hline \multirow[t]{5}{*}{1.} & \multirow[t]{5}{*}{ Material } & Actor & 39 & $\begin{array}{c}21, \\
2\end{array}$ \\
\hline & & Goal & 31 & $\begin{array}{c}16 \\
8\end{array}$ \\
\hline & & Client & 5 & $\begin{array}{c}2,7 \\
2\end{array}$ \\
\hline & & Recipient & 3 & $\begin{array}{c}1,6 \\
3\end{array}$ \\
\hline & & Range & 19 & $\begin{array}{c}10, \\
3\end{array}$ \\
\hline \multirow[t]{2}{*}{2.} & \multirow[t]{2}{*}{ Mental } & Senser & 7 & 3,8 \\
\hline & & $\begin{array}{l}\text { Phenomeno } \\
n\end{array}$ & 11 & $\begin{array}{c}5,9 \\
8\end{array}$ \\
\hline \multirow[t]{2}{*}{3.} & \multirow{2}{*}{$\begin{array}{l}\text { Relational } \\
\text { Attributive }\end{array}$} & Carrier & 7 & 3,8 \\
\hline & & Attribute & 8 & $\begin{array}{c}4,3 \\
5\end{array}$ \\
\hline \multirow[t]{2}{*}{4.} & \multirow[t]{2}{*}{$\begin{array}{l}\text { Relational } \\
\text { Identifying }\end{array}$} & Token & 8 & $\begin{array}{c}4,3 \\
5\end{array}$ \\
\hline & & Value & 8 & $\begin{array}{c}4,3 \\
5\end{array}$ \\
\hline 5. & $\begin{array}{l}\text { Behavioura } \\
l\end{array}$ & Behaver & 4 & $\begin{array}{c}2,1 \\
7\end{array}$ \\
\hline \multirow[t]{3}{*}{6.} & \multirow[t]{3}{*}{ Verbal } & Sayer & 17 & $\begin{array}{c}9,2 \\
4\end{array}$ \\
\hline & & Receiver & 2 & $\begin{array}{c}1,0 \\
9\end{array}$ \\
\hline & & Verbiage & 10 & $\begin{array}{c}5,4 \\
3\end{array}$ \\
\hline \multirow[t]{2}{*}{7.} & Existential & Existent & 5 & $\begin{array}{c}2,7 \\
2\end{array}$ \\
\hline & & Total & $\begin{array}{c}12 \\
3\end{array}$ & 100 \\
\hline
\end{tabular}

Pada Tabel 2 di atas dapat dilihat bahwa partisipan yang paling mendominasi teks pemberitaan adalah partisipan aktif proses material, yaitu actor (39\%), diikuti oleh partisipan pasif proses material, yaitu goal (31\%) dan range $(10,3 \%)$.

Hal tersebut mengindikasikan bahwa dalam artikelnya, KAFFAH cenderung memiliki sudut pandang bahwa LGBT merupakan fenomena yang melibatkan adanya pelaku aktif dan sasaran dari proses material tertentu, baik itu proses material berupa happening maupun doing. 


\section{Sirkumtan}

Sirkumtan merupakan elemen terakhir dalam analisis transitivitas. Dalam sebuah klausa, sirkumtan direalisasikan oleh kata keterangan atau preposisi. Sirkumtan dapat didefinisikan sebagai lingkungan, sifat, atau lokasi tempat berlangsungnya suatu proses. Sirkumtan terbagi menjadi enam jenis, yaitu extent, location, manner, cause, contingency, accompaniment, role, matter, dan angle. Analisis Sirkumtan berfungsi untuk mengeksplisitkan keterangan yang mendampingi proses dan partisipan. Jenis dan frekuensi kemunculan sirkumtan dalam teks media KAFFAH dapat dilihat pada Tabel 3.

Tabel 3. Jenis Sirkumtan dan Kemunculannya dalam artikel buletin KAFFAH

\begin{tabular}{|c|c|c|c|c|}
\hline No. & \multicolumn{2}{|c|}{ Circumtances } & $\mathrm{F}$ & $\%$ \\
\hline \multirow[t]{3}{*}{1.} & Extent & Distance & 0 & 0 \\
\hline & & Duration & 4 & $\begin{array}{c}7,0 \\
2\end{array}$ \\
\hline & & Frequency & 1 & $\begin{array}{c}1,7 \\
5\end{array}$ \\
\hline \multirow[t]{2}{*}{2.} & Location & Place & 1 & 21 , \\
\hline & & Time & 9 & $\begin{array}{c}15, \\
8\end{array}$ \\
\hline \multirow[t]{4}{*}{3.} & Manner & Means & 2 & $\begin{array}{c}3,5 \\
1\end{array}$ \\
\hline & & Quality & 5 & $\begin{array}{c}8,7 \\
7\end{array}$ \\
\hline & & $\begin{array}{l}\text { Compariso } \\
n\end{array}$ & 0 & 0 \\
\hline & & Degree & 0 & 0 \\
\hline \multirow[t]{3}{*}{4.} & Cause & Reason & 2 & $\begin{array}{c}3,5 \\
1\end{array}$ \\
\hline & & Purpose & 1 & $\begin{array}{c}1,7 \\
5\end{array}$ \\
\hline & & Behalf & 0 & 0 \\
\hline \multirow[t]{3}{*}{5.} & Contingency & Condition & 5 & $\begin{array}{c}8,7 \\
7\end{array}$ \\
\hline & & Concession & 0 & 0 \\
\hline & & Default & 0 & 0 \\
\hline \multirow[t]{2}{*}{6.} & $\begin{array}{l}\text { Accompanime } \\
n t\end{array}$ & Comitation & 1 & $\begin{array}{c}1,7 \\
5\end{array}$ \\
\hline & & Addition & 0 & 0 \\
\hline \multirow[t]{2}{*}{7.} & Role & Guise & 4 & $\begin{array}{c}7,0 \\
2\end{array}$ \\
\hline & & Product & 1 & $\begin{array}{c}1,7 \\
5\end{array}$ \\
\hline 8. & Matter & & 2 & $\begin{array}{c}3,5 \\
1\end{array}$ \\
\hline 9. & Angle & & 8 & 14 \\
\hline
\end{tabular}

\begin{tabular}{lll}
\hline Total & 5 & 100 \\
& 7 & 100 \\
\hline
\end{tabular}

Pada Tabel 3 di atas, dapat dilihat bahwa jenis sirkumtan yang paling mendominasi teks adalah sirkumtan location kategori place $(21,1 \%)$, diikuti oleh sirkumtan location kategori time $(15,8 \%)$

Hal tersebut mengindikasikan bahwa dalam pemberitaannya media KAFFAH cenderung memberikan keterangan eksplisit mengenai tempat dan waktu terjadinya sebuah proses. Salah satu sirkumtan location kategori place ini terlihat dari penggunaan kata tempat seperti "tanah air". Berdasarkan hal tersebut dapat diasumsikan bahwa hal yang menjadi fokus dalam artikel KAFFAH adalah fenomena LGBT di Indonesia sebagai tanah air masyarakat Indonesia.

Sementara itu, untuk penggunaan sirkumtan location kategori time terlihat dalam kalimat "Sampai hari ini hubungan seksual sejenis yang dilakukan kaum gay masih menjadi penyebab utama penularan HIV/AIDS". Sirkumtan sampai hari ini dalam kalimat tersebut menunjukkan adanya suatu proses atau kejadian yang masih terus berulang hingga saat ini atau menggambarkan sesuatu hal yang diupayakan (sejak lama) agar berhenti namun masih saja berlangsung hingga saat ini.

Penggunaan kalimat tersebut menunjukkan bahwa buletin Kaffah menunjukkan sifat yang negatif terhadap legalisasi LGBT di Indonesia. Sirkumtan ini pun secara tidak langsung memunculkan opini pembaca bahwa kehadiran LGBT adalah suatu hal yang banyak menghadirkan kemudhorotan dan merupakan suatu ancaman yang nyata dalam kehidupan, baik dari aspek kesehatan maupun sosial. 
Transitivitas dan Pengaruhnya Terhadap Representasi LGBT

Frekuensi kemunculan unsur transitivitas dalam artikel buletin KAFFAH menjadi dasar representasi LGBT dalam perspektif ideologi khilafah.

Secara umum, LGBT dalam perspektif ideologi khilafah direpresentasikan dalam konotasi yang sangat negatif. Hal ini terlihat dari penggunaan kata-kata berkonotasi negatif yang dikaitkan dengan LGBT, seperti ancaman, perbuatan bejat, dan kejahatan.

Melalui proses dan partisipan yang muncul dalam artikel media KAFFAH, LGBT cenderung dipandang sebagai sebuah gerakan global yang berkonotasi buruk. Hal ini terlihat dari bagaimana media menyandingkan LGBT dengan proses berkonotasi negatif. Misalnya dalam klausa kompleks "LGBT kerap menyerang anak-anak", "LGBT tak segan melakukan kekerasan seksual terhadap anak-anak." Penggunaan proses yang dilekatkan pada partisipan "LGBT" tersebut memberikan persepsi bahwa LGBT merupakan seorang pelaku kejahatan atau kriminal.

Penggunaan proses dan partisipan tersebut bukan tanpa maksud. Hal ini tentu untuk menggiring opini pembaca. Representasi ini jelas berbeda jika melihat pada penelitian yang dilakukan Fatinova (2018) yang menunjukkan bahwa dalam media Kompas, LGBT malah LGBT direpresentasikan sebagai entitas yang mendapatkan kekerasan.

Selain itu, dalam artikel buletin KAFFAH LGBT didefinisikan sebagai sebuah ancaman. Hal ini terlihat dari proses relational identifying dengan value negatif yang disematkan pada entitas LGBT, seperti dalam klausa kompleks " $L G B T$ adalah ancaman nyata." Pemberian value negatif tersebut mengindikasikan bahwa menurut ideologi khilafah, LGBT ini bukan hanya sekedar masalah orientasi seksual, tetapi menyangkut masalah sosial yang lebih kompleks.

Penggunaan diksi "ancaman" secara tidak langsung merepresentasikan LGBT sebagai sesuatu yang berbahaya, yang melibatkan adanya pelaku dan sasaran. Dalam klausa kompleks tersebut sasaran yang dimaksud tidak dimunculkan karena klausa berbentuk proses relational identifying. Berbeda kasusnya jika konstruksinya berbentuk proses material. Hal ini tidak dapat dikatakan tidak ada tujuan di balik pemilihan proses tersebut, hal ini dapat dikatakan untuk mengeneralisasi partisipan.

Lebih lanjut, pernyataan ini diperkuat dengan penggunaan proses mental dalam klausa kompleks "LGBT seharusnya sudah dianggap sebagai ancaman terhadap negeri". Penggunaan klausa kompleks tersebut mengindikasikan bahwa ada pihak-pihak yang masih menganggap LGBT sebagai sesuatu yang tidak mengancam. Tentu berdasarkan perspektif ideologi khilafah hal ini adalah sebuah kekeliruan, karena seharusnya masyarakat sadar bahwa LGBT adalah bahaya yang nyata.

Lebih jauh, perilaku LGBT pun disebutkan sebagai tersangka utama dalam penyebaran penyakit AIDS dan kanker anal. Pernyataan ini diungkapkan KAFFAH melalui penggunaan proses material berkonotasi negatif yang menjadikan "LGBT" sebagai partisipan aktif (actor). Hal ini terlihat dalam klausa kompleks "LGBT bukan saja mengubah perilaku sosial, tetapi juga menyebarkan wabah HIV/AIDS dan kanker anal." Dalam klausa kompleks tersebut, KAFFAH seolah-olah melakukan generalisasi bahwa AIDS dan kanker anal hanya diakibatkan oleh perilaku LGBT. Pada faktanya, seperti dikutip melalui Alodokter.com, kanker anal bisa disebabkan oleh beberapa faktor, seperti usia, pergantian pasangan seksual, melakukan seks anal, merokok, dan lain sebagainya. 
Di samping itu, KAFFAH pun mendeskripsikan LGBT sebagai tindakan kriminal berkategori kejahatan jarimah. Hal tersebut terlihat dari klausa kompleks "LGBT adalah kejahatan/tindak kriminal (jarimah)!" Hal ini dirasa kurang tepat, karena kejahatan jarimah tidak berlaku di Indonesia secara holistik, tetapi hanya berlaku di Aceh sebagai satu-satunya daerah di Indonesia yang menetapkan aturan Islam sebagai landasan hukum. Hal ini tercantum dalam Qanun Aceh No.6 Tahun 2014 point C. Berdasarkan Qanun Aceh pun hanya homoseksual saja yang dapat dikategorikan sebagai kejahatan jarimah, lebih tepatnya kejahatan jarimah kategori liwath.

Kejahatan jarimah didefinisikan sebagai tindak pidana yang dilarang oleh Syariat Islam. Tindak pidana yang termasuk kejahatan jarimah salah satunya adalah kejahatan liwath. Hukuman bagi tindak pidana liwath berdasarkan Qanun Aceh bagian kesepuluh Pasal 63 Ayat 1 adalah hukuman seratus (100) kali cambuk.

Jika dicermati mengenai definisi kejahatan jarimah dalam Qanun Aceh, hanya homoseksual yang dapat dikenakan sanksi atau hukuman. Sementara untuk lesbian, biseksual, dan trans-gender tidak dapat dikenakan sanksi. Hal ini dikarenakan tidak adanya klausul yang secara gamblang menyatakan lesbian, biseksual, dan trans-gender merupakan kejahatan jarimah, pun kejahatan lainnya.

Sementara liwath didefinisikan sebagai "perbuatan seorang laki-laki dengan cara memasukkan zakarnya ke dalam dubur laki-laki yang lain dengan kerelaan kedua belah pihak." Mengacu pada definisi tersebut, dapat disimpulkan bahwa homoseksual dapat dikategorikan sebagai tindak pidana jika sudah pada tahap terjadinya hubungan badan. Sementara jika seseorang hanya menyandang status sebagai homoseksual, tidak ada klausul yang secara tegas menyatakan bahwa hal tersebut termasuk tindak pidana.

Kategori LGBT sebagai kejahatan jarimah dalam media KAFFAH dapat dimaksudkan sebagai strategi untuk menekankan kepada pembaca bahwa LGBT berdasarkan hukum adalah sebuah tindak pidana. Padahal yang dimaksud adalah "perbuatannya" bukan "statusnya," itu pun hanya berlaku di Aceh tidak seluruh Indonesia.

Melalui hal tersebut, dapat dikatakan bahwa media KAFFAH menunjukkan pendapatnya melalui perspektif aturan Islam dengan mengutip hukum yang berlaku di Aceh, bukan melalui perspektif landasan hukum yang berlaku di Indonesia.

Selanjutnya, untuk lebih menguatkan pijakannya, media KAFFAH menjadikan "Nabi" sebagai sayer dari proses verbal "memperingatkan" di mana yang menjadi target dari proses tersebut adalah "umat muslim". Hal ini menjadi penting untuk diperhatikan karena penggunaan partisipan tertentu dalam sebuah teks memiliki tujuan untuk membangun sebuah objektivitas pada pemberitaan. ${ }^{28}$

Berikut peringatan yang dinyatakan oleh Nabi melalui sebuah Hadis:

Nabi bersabda: "kelak kalian akan mengikuti perilaku umat sebelum kalian sehasta demi sehasta, sedepa demi sedepa. Bahkan mereka masuk ke lubang biawak pun kalian ikuti." Kami bertanya, "Duhai Rasulullah, apakah mereka Yahudi dan Nasrani?" Beliau menjawab, "Siapa lagi?!" (HR

\section{Muttafaq alayh).}

Hadits tersebut secara umum menjelaskan mengenai Tasyabbuh. Penggunaan Hadis tersebut mengindikasikan bahwa KAFFAH mendefinisikan LGBT sebagai perbuatan kaum Nashrani dan Yahudi terdahulu

${ }^{28}$ Eriyanto, Analisis Framing: Konstruksi, Ideologi, Dan Politik Media. 
seharusnya tidak diikuti oleh kaum muslim pada jaman sekarang.

Hal tersebut tentu dirasa kurang tepat, karena bukan hanya Islam yang melarang LGBT, tetapi seluruh agama tidak ada yang memperkenankan LGBT. Di samping itu, para pemuka lintas agama telah menyatakan dengan tegas bahwa LGBT merupakan perilaku yang menyimpang dari agama dan hukum alam. $^{29}$

Lebih lanjut, media KAFFAH kemudian mengungkapkan siapa saja pihak yang berkontribusi dalam mengampanyekan LGBT di Indonesia, baik itu kelompok maupun individual. Hal ini terlihat melalui partisipan-partisipan yang dimunculkan dalam teks. Misalnya partisipan "negara-negara Barat", seperti dalam klausa kompleks "Negara-negara Barat telah mengerahkan dana yang besar, melibatkan lembaga-lembaga internasional dan memanfaatkan antekantek mereka untuk mengampanyekan LGBT ke tengah-tengah kita." Dalam klausa tersebut, negara-negara Barat ditempatkan sebagai actor yang berperan dalam mengampanyekan LGBT di Indonesia.

Partisipan "negara-negara Barat" dalam klausa tersebut berbentuk indetermination. Konsekuensinya adalah identitas partisipan yang dimaksud menjadi taksa. Hal ini merupakan sebuah strategi agar pembaca tidak mempertanyakan validitas keabsahan sebuah sumber. ${ }^{30}$ Namun, di sisi lain pernyataan ini dapat diragukan kebenarannya karena media sama sekali tidak menyatakan identitas yang menyatakan hal tersebut.

Di samping itu, KAFFAH pun mengungkapkan para tokoh yang cenderung mendukung eksistensi LGBT di Indonesia, salah satunya adalah Luhut Binar Pandjaitan sebagai Menko
Polhukam. Hal ini terlihat melalui klausa kompleks "Luhut Binar Pandjaitan yang kala itu menjabat Menko Polhukam mengatakan bahwa kaum LGBT punya hak untuk dilindungi oleh negara karena mereka adalah warga negara Indonesia."

Jika kembali pada UUD 1945 sebagai landasan hukum negara, apa yang dinyatakan oleh Luhut Binar Panjaitan tidak salah. Kaum LGBT, selama dia masih merupakan warga Indonesia, mereka memiliki hak untuk diakui. Hal tersebut tercantum dalam UUD 1945 Pasal 28I Ayat 1 yang menyatakan bahwa:

"setiap masyarakat memiliki hak untuk tidak disiksa, hak kemerdekaan pikiran dan hati nurani, dan hak untuk diakui secara pribadi di depan hukum."

Selain Luhut Binar Panjaitan, partisipan lain yang dimunculkan KAFFAH sebagai pihak yang cenderung mendukung keberadaan LGBT di Indonesia adalah Eva Sundari dari PDIP, Rahayu Saraswati dari Gerindra, Lukman Hakim Menteri Agama RI.

Selanjutnya, aspek sirkumtan menunjukkan bahwa media ini cenderung menyoroti fenomena LGBT di Indonesia yang semakin meresahkan. Hal ini terlihat melalui elemen sirkumtan kategori place yang mendominasi teks pada artikel media KAFFAH. Place yang umunya dimunculkan oleh media KAFFAH adalah Indonesia, tanah air, dan beberapa daerah di Indonesia. Hal ini mengindikasikan bahwa media ini ingin menginformasikan kepada masyarakat bahwa pergerakan LGBT di Indonesia sudah semakin meluas ke beberapa daerah yang ada di Indonesia.

Berdasarkan unsur-unsur transitivitas yang mendasari teks pada media KAFFAH, jelas terlihat bahwa media ini mengusung ideologi khilafah. LGBT ini direpre-sentasikan sebagai bencana yang mengancam bangsa. Pertumbuhan

\footnotetext{
${ }^{29}$ Winurini, "Memaknai Perilaku LGBT Di Indonesia (Tinjauan Psikologi Abnormal)."

${ }^{30}$ Hart, Discourse, Grammar, and Ideology.
} 
populasi LGBT merupakan dampak dari sikap tidak tegas pemerintah dalam membuat Undang-undang yang tidak dapat menjerat LGBT. Seperti diketahui, dalam RUU KUHP Pasal 492 ada limitasi di mana homoseksual dikatakan sebagai tindak pidana hanya jika pelaku masih berusia kurang dari 18 tahun, sementara 18 tahun ke atas tidak ada dasar hukumnya. Dinyatakan pula bahwa perkembangan LGBT dipengaruhi pula oleh sebagian persepsi masyarakat yang memang sejak awal mentolerir eksistensinya di Indonesia.

Selanjutnya, dari kacamata ideologi khilafah yang tergambar dalam teks media KAFFAH, solusi yang paling tepat untuk menghentikan penyebaran LGBT di Indonesia adalah dengan cara mengubah aturan yang ada dan menerapkan aturan Islam sebagai landasan hukum negara.

Berkaitan dengan hal tersebut, Yusril sebagai Pakar Hukum Tatanegara di salah satu stasiun televisi swasta pernah menyatakan bahwa hukum Islam dapat ditransformasi menjadi hukum positif Indonesia dengan tidak mengubah dasar negara, yaitu Pancasila dan UUD 1945. Ini artinya aturan Islam hanya dapat diadopsi tetapi tidak menjadi landasan hukum negara.

Sejatinya, permasalahan LGBT ini dapat diatasi melalui penerapan nilai-nilai Pancasila, karena sejatinya dalam Pancasila terdapat nilai kemanusiaan yang tidak boleh bertentangan dengan nilai ketuhanan. $^{31}$

\section{Kesimpulan}

Berdasarkan hasil analisis dan pembahasan di atas, maka dapat ditarik simpulan sebagai berikut: dalam perspektif ideologi khilafah yang tergambar melalui teks media KAFFAH, LGBT direpresentasikan sebagai sebuah gerakan yang mengancam keseimbangan bangsa. Tindakan LGBT

\footnotetext{
${ }^{31}$ Harahap, Kamalludin, and Arzaqi, "Kebijakan
} Hukum Pidana Dalam Upaya Menanggulangi direpresentasikan sebagai sebuah kejahatan yang pantas untuk mendapatkan hukuman mati. Di samping itu, pelaku LGBT khususnya kaum homoseksual direpresentasikan sebagai predator anak dan remaja. Hal ini jelas terlihat dari penggunaan unsur-unsur transitivitas yang mendasari teks.

Selanjutnya, jika ditinjau dari cara pemberitaan, media KAFFAH cenderung memiliki bias media. Terlihat dari bagaimana media ini memberitakan LGBT hanya dari sisi negatifnya saja. Hal ini tidak tepat karena pemberitaan seharusnya berimbang.

Selanjutnya, media KAFFAH pun mengusulkan sebuah solusi untuk menanggulangi fenomena LGBT di Indonesia. Dalam perspektifnya, dinyatakan bahwa satu-satunya cara untuk menghentikan LGBT adalah dengan bersatunya umat Islam. kemudian menegakkan syariat Islam di tanah air.

Namun, hal tersebut tampaknya sulit untuk direalisasikan. Sebagaimana yang diungkapkan oleh Maruf Amin bahwa konsep khilafah sendiri tertolak di Indonesia. Tampaknya hal ini dikarenakan Indonesia memiliki landasan hukumnya sendiri, yaitu Pancasila dan UUD 1945. Pancasila dan UUD merupakan landasan hukum negara yang tidak bertentangan dengan nilai-nilai agama, ungkapnya.

Sebenarnya, LGBT dapat dikategorikan sebagai perbuatan yang bertentangan dengan nilai ketuhanan dan menyimpang dari nilai religiusitas. Kaum LGBT selama ini berlindung atas nama HAM yang berlaku di negara Barat atau HAM Universal. Hal ini menunjukkan bahwa LGBT bersandar pada ideologi liberalisme dan universalisme yang

LGBT (Lesbian, Gay, Biseksual, Dan Transgender) Berbasis Pancasila." 
bertentangan dengan nilai, norma, dan hukum nasional Indonesia. ${ }^{32}$

Padahal, Indonesia menganut HAM partikularisme di mana perilaku seperti zina dan LGBT dapat dipidanakan atas pertimbangan lokal dan kebutuhan masyarakat. Prinsip dasar HAM ini adalah hukum melayani masyarakat. Hal ini diungkapkan oleh Mahfud MD sebagai mantan ketua Mahkaman Konstitusi (MK).

Lebih lanjut, LGBT seharusnya dikategorikan sebagai tindak pidana karena telah menimbulkan kerusakan yang bersifat individu maupun sosial. ${ }^{33}$ Pemidanaan ini ditujukan untuk perbaikan diri pelaku LGBT itu sendiri.

Salah satu negara yang telah mengategorikan LGBT sebagai tindakan pidana adalah negara Singapura. Dalam hukum yang berlaku di Singapura, LGBT termasuk dalam kejahatan Asusila. Hal ini tertuang dalam Pasal 377A KUHP yang menyatakan bahwa:

“[...] Setiap laki-laki yang, di depan umum atau tertutup, melakukan, atau menjalankan perintah, atau mendapatkan atau mencoba untuk mendapatkan komisi (tindakan seksual) oleh laki-laki mana pun, setiap tindakan kasar terhadap orang lain, akan dihukum penjara untuk masa hukuman yang bisa berlanjut hingga 2 tahun." "34

Sementara di Indonesia sendiri, hukum bagi LGBT masih belum jelas. Meskipun keberadaan LGBT di Indonesia sudah terbilang cukup lama, yaitu sudah ada sejak tahun 1960-an. Ideologi khilafah menginginkan hukum yang dapat menjerat LGBT sebagai tindak pidana. Hal ini dilakukan sebagai upaya meminimalisir pertumbuhan populasi LGBT di Indonesia.

\footnotetext{
${ }^{32}$ Suranto, Herlina, and Setiawan, "Agama Dan Media Diskursus LGBT Dalam Opini SKH Republika."

${ }^{33}$ Harahap, Kamalludin, and Arzaqi, "Kebijakan Hukum Pidana Dalam Upaya Menanggulangi
}

\section{Daftar Pustaka}

Artina, Dessy. "Kedudukan LGBT Dalam Hukum Negara Republik Indonesia Ditinjau Dari Perspektif Pancasila." Seminar Nasional Hukum Universitas Negeri Semarang 2, no. 1 (2016): 195-206.

Eriyanto. Analisis Framing: Konstruksi, Ideologi, Dan Politik Media. Yogyakarta: LKis Group, 2012.

Fatinova, Dede. "Representasi LGBT (Lesbian, Gay, Biseksual, Dan Transgender) Dalam Pemberitaan Di Kompas.Com Dan Republika.Co.Id (Kajian Linguistik Sistemik Fungsional)." Bandung, 2018.

Halliday, M.A.K, and C.M Mathiessen. Halliday's Introduction to Functional Grammar. New York: Routledge, 2014.

Hanifudin, Muhammad. "Kaffah HTI Masih Tersebar Luas, Bagaimana Cara Menyikapinya?," 2019. https://islami.co/buletin-kaffahhti-masih-tersebar-luasbagaimana-cara-menyikapinya/.

Harahap, Indra Tua Hasangapon, Iqbal Kamalludin, and Nilla Arzaqi. "Kebijakan Hukum Pidana Dalam Upaya Menanggulangi LGBT (Lesbian, Gay, Biseksual, Dan Transgender) Berbasis Pancasila." Masalah-Masalah Hukum 47, no. 4 (2018): 400-412. Harahap, Rustam Dahar Karnadi Apollo. "LGBT Di Indonesia: Perspektif Hukum Islam, HAM, Psikologi, Dan Pendekatan Maslahah." $\mathrm{Al}$ Ahkam 26, no. 2 (2016): 223-48.

Hart, Christoper. Discourse, Grammar, and Ideology. New York: Bloomsburry, 2014.

LGBT (Lesbian, Gay, Biseksual, Dan Transgender) Berbasis Pancasila."

${ }^{34}$ Harahap, Kamalludin, and Arzaqi. 
Heck, Marina Camargo. Culture, Media, and Language. New York: Routledge, 2005.

Husaini, Adian. LGBT Di Indonesia: Perkembangan Dan Solusinya. Jakarta: INSISTS, 2015.

Irawan, Edi. "Irawan, Edi. 2017. Hukuman Bagi Pelaku Homoseksual Dan Lesbian Dalam Perspektif Hukum Islam Dan Hukum Positif.” Jakarta, 2017.

Jaelani, Jejen, and Tri Sulistyaningtyas. "Kontroversi Khilafah: Islam, Negara, Dan Pancasila." Jurnal Sosioteknologi 14, no. 2 (2015).

Kartini, Indriana. "Hizbut Tahrir Indonesia and the Idea of Restoring Islamic Caliphate." Masyarakat Indonesia 41, no. 1 (2015): 1-14.

Katjasungkana, Nursyahbani, and Saskia

E Wieringa. Kriminalisasi Merayap: Pemetaan UndangUndang Nasional Serta Peraturan Daerah Di Indonesia Yang Melanggar Hak Asasi Perempuan Dan Kelompok LGBTQ. New York: Outright Action International, 2016.

Lingga, Murti Ali, and Hamdani M Syam. "Analisis Framing Pemberitaan Lesbian, Gay, Biseksual Dan Transgender (LGBT) Pada Media Online Republika.Co.Id Dan Tempo.Co." Ilmiah Mahasiswa FISIP Unsyiah 3, no. 1 (2018).

Maskur, Fatkhul. "LGBT Lebih Berbahaya Ketimbang Terorisme \& Narkoba," 2016.

mm. "Buletin Jumat Kaffah HTI Sebarkan Anti Islam Nusantara," 2018. https://bangkitmedia. com/ buletin-jumat-kaffah-htisebarkan-anti-islam-nusantara/.

Movanita, Ambaranie Nadia Kemala. "HTI Resmi Dibubarkan Pemerintah?," 2017. https://nasional.kompas.com/read /2017/07/19/10180761/hti-resmidibubarkan-pemerintah?page=all. Munfarida, Elya. "Analisis Wacana Kritis Dalam Perspektif Norman Fairclough," 1978, 1-19.

Nirwanto, Gisela Dea. "Pembingkaian Berita Pro Kontra LGBT Di Laman Topik Pilihan Kompas.Com (How Kompas.Com Frame News on the Pros and Cons of LGBT in Their Selected Topics Page)." Jurnal EKomunikasi 4, no. 1 (2016).

Prasetya, Adhi Indra. "Wiranto Tegaskan Eks HTI Dilarang Sebar Paham Khilafah,"2019. https://news. detik. com/berita/d-4631220/ wiranto-tegaskan-eks-htidilarang-sebar-paham-khilafah.

Pratiwi, Ardhina. "Konstruksi Realitas Dan Media Massa (Analisis Framing Pemberitaan Lgbt Di Republika Dan Bbc News Model Robert N. Entman)." Thaqafiyyat: Jurnal Bahasa, Peradaban Dan Informasi Islam 19, no. 1 (2018): 50-71.

Putra, Muhammad Ghifari, and Kharisma Nasionalita. "Isu Lgbt Dalam Bingkai Media Online" 1 , no. 1 (2009): 1-14.

Rauf, Moh. Abd. "The Implication of Caliphate Ideology Movements against the Implementation of Democracy toward Jember Society." Fikrah: Jurnal Ilmu Aqidah Dan Studi Keagamaan 6, no. 1 (2018): 209-28.

Sabara. "Hizbut-Tahrir in Da'wah and Islamic Political Movements in Indonesia." JISCA 6, no. 2 (2017): 271-94.

Shobron, Sudarno. "Model Dakwah Hizbut Tahrir Indonesia." Profetika Jurnal Studi Islam 15, no. 1 (2014): 44-62.

Sobur, Alex. Analisis Teks Media: Suatu Pengantar Untuk Analisis 
Wacana. Analisis Semiotik Dan Analisis Framing, 2006. https://doi.org/10.1177/15248380 07302594.

Suranto, Dyna Herlina S, and Benny Setiawan. "Agama Dan Media: Diskursus LGBT Dalam Opini SKH Republika." Komuniti 9, no. 2 (2017): 105-17.

Suranto, Dyna Herlina, and Benni Setiawan. "Agama Dan Media Diskursus LGBT Dalam Opini SKH Republika," 2016, 105-17.

Syamsul, Arifin. "Buletin Kaffah Diduga Milik HTI Masih Menyebar Di Jombang," 2018. https://www. nu.or.id/post/read/86 255/buletinkaffah-diduga-milik-hti-masihmenyebar-di-jombang.

Tim Legality. KUHP (Kitab Dan Undang-Undang Hukum Pidana) Dan KUHAP (Kitab UndangUndang Hukum Acara Pidana). Yogyakarta: LEGALITY, 2017.
Winurini, Sulis. "Memaknai Perilaku LGBT Di Indonesia (Tinjauan Psikologi Abnormal)." Pusat Penelitian Badan Keahlian DPR RI, 2016, 99-12.

Wiratno, Tri. Pangantar Ringkas Linguistik Sistemik Fungsional. 1st ed. Yogyakarta: Pustaka Pelajar, 2018.

Yansyah, Roby, and Rahayu. "Globalisasi Lesbian, Gay, Biseksual, Dan Transgender (LGBT): Perspektif HAM Dan Agama Dalam Lingkup Hukum Di Indonesia." Law Reform 14, no. 1 (2018): 132-46.

Yudah, Anindita Ayu Pradipta, and Iqrak Sulhin. "Representasi Transgender Dan Transeksual Dalam Pemberitaan Di Media Massa: Sebuah Tinjauan Analisis Wacana Kritis.” Depok, 2014. 
Dede Fatinova, dkk, Representasi LGBT dalam Perspektif .. 